\title{
From Pigs to Patients: Transmissible, Single Gene-mediated Resistance to Colistin
}

\author{
Joseph B McPhee ${ }^{1}$ and Shawn Lewenza ${ }^{2 *}$ \\ ${ }^{1}$ Department of Chemistry and Biology, Ryerson University, Toronto, Ontario, Canada \\ ${ }^{2}$ Faculty of Science and Technology, Athabasca University, Athabasca, Alberta, Canada
}

*Corresponding author: Shawn Lewenza, Faculty of Science and Technology, Athabasca University, Athabasca, Alberta, Canada, Tel: 17806752438; E-mail: slewenza@athabascau.ca

Rec date: Dec 30, 2015; Acc date: Feb 23, 2016; Pub date: Feb 26, 2016

Copyright: @ 2016 McPhee JB, et al. This is an open-access article distributed under the terms of the Creative Commons Attribution License, which permits unrestricted use, distribution, and reproduction in any medium, provided the original author and source are credited.

\section{Commentary}

The last decade has seen a stark increase in the number of multidrug resistant Gram-negative bacterial pathogens. Of particular importance are highly carbapenem resistant Escherichia coli and Klebsiella pneumoniae, as well as fluoroquinolone resistant Pseudomonas aeruginosa and Acinetobacter baumanii [1]. Owing to the lack of new drugs entering the marketplace, physicians are increasingly revisiting older drugs that had fallen out of common use. One such drug is colistin and it has increasingly become the drug of last resort for these infections [2]. Colistin is a polymyxin type of antimicrobial lipopeptide that is produced by Paenobacillus species. The polymxyins were discovered 65 years ago but have limited clinical use due to their neurotoxic and nephrotoxic side effects. Despite this toxicity in humans, colistin is used extensively in agriculture as growth promoters and estimates of global colistin usage in agriculture is $>12,000$ tonnes per annum. A recent report in the Lancet Infectious Diseases describes the first example of a transmissible plasmid that encodes colistin resistance by the mcr-1 gene. Colistin resistance was first detected in Escherichia coli isolates from pigs, but was ultimately found in meats for sale, and later in Chinese patients [3].

Clinical resistance to colistin is largely mediated through the modification of lipopolysaccharide via the addition of ethanolamine or 4-amino-arabinose to free phosphate moieties on the lipid A moiety. These additions reduce the negative charge and limit antimicrobial peptide binding and membrane disruption [4,5]. The emergence of clinical resistance to colistin is due to point mutations in regulatory proteins that control the genes responsible for these additions, PhoPQ and/or PmrAB (and MgrB in K. pneumoniae) and were transmitted only vertically [6-9]. These data suggest that contrary to a common argument put forward by those developing novel antimicrobial peptides, resistance to this antibiotic class is common and now transmissable as single gene determinants.

The mcr-1 gene encodes a phosphoethanolamine transferase that adds a phosphoethanolamine to the phosphate groups of hexa-acylated lipid A, thereby blocking the negatively charged phosphates on lipid A, which otherwise serve as the binding site of cationic antimicrobial peptides [3,5]. The plasmid encoding $m c r-1$ is highly transmissible by conjugation to other $E$. coli isolates, and by transformation to other Gram-negative pathogens, resulting in 8-16 fold increases in colistin resistance [3]. In addition, the $m c r-1$ gene was active in an animal model of infection, demonstrating that it can provide a survival advantage during colistin-mediated chemotherapy [3]. This is the first description of plasmid-mediated colistin resistance and it represents a very important and worrisome development in infectious disease control.
In subsequent reports, the mcr- 1 gene was found in food isolates of Salmonella enterica from Portugal and France $[10,11]$, in six healthy individuals in Laos, Algeria and Thailand [12], in the gut micro biomes of healthy and diabetic Chinese subjects [13] and in E. coli samples from a prospective study of Dutch patients travelling to Southeast Asia [14]. Unpublished reports have also identified the $m c r-1$ gene in $S$. enterica and $E$. coli isolates in England and Wales, including at least 2 isolates from patients [15]. Perhaps most worrisome, the $\mathrm{mcr}-1$ gene was found in an E. coli blood-borne infection isolate from a Danish patient with recurrent UTIs [15]. While the original report demonstrated that the $m c r-1$ gene was found on an IncI2 type plasmid, these short reports found the gene on IncX4 type plasmids as well showing that the gene is present in more than one plasmid type. While this is a very worrying observation, the $m c r-1$ gene has not yet been linked to any documented evidence of clinical colistin failure in humans.

In the Liu paper, the authors used a murine thigh model to demonstrate the effect of $m c r-1$ on in vivo colistin sensitivity [3]. Of interest, this experiment shows that in the absence of colistin, the $m c r-1+$ strain has a slight fitness defect [3]. Whether this is due to the $m c r-1$ gene itself or other genetic elements on pHNSHP45 is unknown, but it has been well documented that regulatory changes associated with colistin resistance often reduce the fitness of the organism containing those mutations in the absence of selection $[6,7,16,17]$. This suggests that removing the use of colistin may have the added benefit of selecting against the long-term survival of resistant isolates because of their reduced fitness relative to sensitive strains.

In summary, the observation of plasmid-mediated colistin resistance offers yet more evidence that antibiotic usage in agriculture needs to be drastically curtailed if we want to continue to use antibiotics to treat people. China is one of the largest users of colistin in agriculture, although use is widespread in the EU as well. Surveillance data in China has already demonstrated that colistin resistance is widespread in animal isolates. As there is limited development of new antimicrobials, particularly those directed toward Gram-negative pathogens, we ignore this development at our peril. Although this is the first example of plasmid-mediated colistin resistance, it is not likely the last, as there are other single candidate genes that could also lead to colistin resistance. There have been previous studies describing resistance to "last resort" antibiotics, and hopefully this example of colistin resistance will not lead to the "apocalypse pig" [18]. 
Citation: McPhee JB, Lewenza S (2016) From Pigs to Patients: Transmissible, Single Gene-mediated Resistance to Colistin. J Med Microb

Page 2 of 2

\section{References}

1. Boucher HW, Talbot GH, Bradley JS, Edwards JE, Gilbert D, et al. (2009) Bad bugs, no drugs: no ESKAPE! An update from the Infectious Diseases Society of America. Clin Infect Dis 48: 1-12.

2. Biswas S, Brunel J-M, Dubus J-C, Reynaud-Gaubert M, Rolain J-M (2012) Colistin: an update on the antibiotic of the 21st century. Expert Rev. Anti Infect Ther 10: 917-934.

3. Liu Y-Y, Wang Y, Walsh TR, Yi L-X, Zhang R, et al. (2015) Emergence of plasmid-mediated colistin resistance mechanism MCR-1 in animals and human beings in China: a microbiological and molecular biological study. Lancet Infect Dis 16: 161-168.

4. McPhee JB, Lewenza S, Hancock REW (2003) Cationic antimicrobial peptides activate a two-component regulatory system, PmrA-PmrB, that regulates re-sistance to polymyxin $B$ and cationic antimicrobial peptides in Pseudomonas ae-ruginosa. Mol Microbiol 50: 205-217.

5. Olaitan AO, Morand S, Rolain JM (2014) Mechanisms of polymyxin resistance: acquired and intrinsic resistance in bacteria. Front Microbiol 26: 643 .

6. Lesho E, Yoon E-J, McGann P, Snesrud E, Kwak Y, et al. (2013) Emergence of colistin-resistance in extremely drug-resistant Acinetobacter baumannii containing a novel pmrCAB operon during colistin therapy of wound infections. J Infect Dis 208: 1142-1151.

7. Moskowitz SM, Brannon MK, Dasgupta N, Pier M, Sgambati N, et al. (2012) PmrB mutations promote polymyxin resistance of Pseudomonas aeruginosa iso-lated from colistin-treated cystic fibrosis patients. Antimicrob Agents Chemother 56: 1019-30.

8. Quesada A, Porrero MC, Téllez S, Palomo G, García M, et al. (2015) Polymorphism of genes encoding PmrAB in colistin-resistant strains of Escherichia coli and Salmonella enterica isolated from poultry and swine. J Anti-microb Chemother 70: 71-74.

9. Wright MS, Suzuki Y, Jones MB, Marshall SH, Rudin SD, et al. (2015) Genomic and transcriptomic anal-yses of colistin-resistant clinical isolates of Klebsiella pneumoniae reveal multiple pathways of resistance. Antimicrob Agents Chemother 59: 536-543.

10. Tse H, Yuen K-Y (2015) Dissemination of the mcr-1 colistin resistance gene. Lancet Infect. Dis. Published Online: 17th December 2015.

11. Webb HE, Granier SA, Marault M, Millemann Y, Den Bakker HC, et al. (2015) Dissemination of the mcr-1 colistin resistance gene. Lancet Infect. Dis. Published Online: 17 December 2015.

12. Olaitan AO, Thongmalayvong B, Akkhavong K, Somphavong S, Paboriboune P, et al. (2015) Clonal transmission of a colistin-resistant Escherichia coli from a domesticated pig to a human in Laos. J Antimicrob Chemother 70: 3402-3404.

13. Hu Y, Liu F, Lin IYC, Gao GF, Zhu B (2015) Dissemination of the mcr-1 colistin resistance gene. Lancet Infect. Dis. Published Online: 17 December 2015.

14. Arcilla MS, Van Hattem JM, Matamoros S, Melles DC, Penders J, et al. (2015) Dissemination of the mcr-1 colistin resistance gene. Lancet Infect. Dis. Published Online: 17th December 2015.

15. Hasman H, Hammerum AM, Hansen F, Hendriksen RS, Olesen B, et al. (2015) Detection of mcr-1 encoding plasmid-mediated colistin-resistant Escherichia coli isolates from human bloodstream in-fection and imported chicken meat, Denmark. Euro Surveill Bull Eur sur les Mal Transm Eur Commun Dis Bull 20.

16. Choi M-J, Ko KS (2015) Loss of Hypermucoviscosity and Increased Fitness Cost in Colistin-Resistant Klebsiella pneumoniae Sequence Type 23 Strains. Antimi-crob Agents Chemother 59: 6763-6773.

17. Beceiro A, Moreno A, Fernández N, Vallejo JA, Aranda J, et al. (2014) Biological cost of different mechanisms of colistin re-sistance and their impact on virulence in Acinetobacter baumannii. Antimicrob Agents Chemother 58: 518-26.

18. McKenna M (2015) Nov 21st. Apocalypse pig: the last antibiotic begins to fail. http://phenomena.nationalgeographic.com/2015/11/21/mcr-genecolistin 